\title{
Organ damage in Atlantic herring larvae as a result of ocean acidification
}

\author{
Andrea Y. Frommel, ${ }^{1}$ Rommel Maneja, ${ }^{1}$ David Lowe, ${ }^{2}$ Christine K. Pascoe, ${ }^{2}$ Audrey J. Geffen, ${ }^{3}$ \\ Arild Folkvord, ${ }^{3}$ Uwe Piatkowski, ${ }^{1}$ and Catriona Clemmesen ${ }^{1,4}$ \\ ${ }^{1}$ GEOMAR, Helmholtz Centre for Ocean Research Kiel, Duestenbrooker Weg 20, 24105 Kiel, Germany \\ ${ }^{2}$ Plymouth Marine Laboratory, Prospect Place, Plymouth, Devon PL1 3DH United Kingdom \\ ${ }^{3}$ University of Bergen, Nygårdshøyden, 5020 Bergen, Norway
}

\begin{abstract}
The dissolution of anthropogenically emitted excess carbon dioxide lowers the $\mathrm{pH}$ of the world's ocean water. The larvae of mass spawning marine fishes may be particularly vulnerable to such ocean acidification $(\mathrm{OA})$, yet the generality of earlier results is unclear. Here we show the detrimental effects of $\mathrm{OA}$ on the development of a commercially important fish species, the Atlantic herring (Clupea harengus). Larvae were reared at three levels of $\mathrm{CO}_{2}$ : today $(0.0385 \mathrm{kPa})$, end of next century $(0.183 \mathrm{kPa})$, and a coastal upwelling scenario $(0.426$ $\mathrm{kPa}$ ), under near-natural conditions in large outdoor tanks. Exposure to elevated $\mathrm{CO}_{2}$ levels resulted in stunted growth and development, decreased condition, and severe tissue damage in many organs, with the degree of damage increasing with $\mathrm{CO}_{2}$ concentration. This complements earlier studies of OA on Atlantic cod larvae that revealed similar organ damage but at increased growth rates and no effect on condition.
\end{abstract}

Key words: Clupea harengus; $\mathrm{CO}_{2}$; fisheries; growth; histology; $\mathrm{pH} ; \mathrm{RNA}: \mathrm{DNA}$.

\section{INTRODUCTION}

Atmospheric $\mathrm{CO}_{2}$ levels are currently rising at a high rate that is largely driven by anthropogenic activities such as burning of fossil fuels and changes in land use (Le Quéré et al. 2009). Approximately one-third of the $\mathrm{CO}_{2}$ in the atmosphere will be absorbed by the oceans, leading to an estimated global drop in $\mathrm{pH}$ of 0.4 units by the year 2100 and up to 0.8 units (partial pressure of $\mathrm{CO}_{2}$ gas $\left[p \mathrm{CO}_{2}\right] \approx 0.203 \mathrm{kPa}$ ) by the year 2300 (Sabine et al. 2004, IPCC 2007). However, the magnitude of change can be locally highly variable (Hofmann et al. 2011). Areas particularly impacted by ocean acidification include coastal upwelling regions, where water with higher than today's average $p \mathrm{CO}_{2}$ level is seasonally upwelled onto the continental shelf (Feely et al. 2008, Fassbender et al. 2011). High latitudes with characteristic cold water, high primary productivity, and melting of sea ice will also be more heavily impacted by ocean acidification (Bellerby et al. 2005, Fabry et al. 2009, Steinacher et al. 2009), and $\mathrm{pH}$ values for the coastal Arctic Ocean are predicted to reach 7.7 by the year 2100 (Denman et al. 2011). In some parts of the Arctic Ocean, the decrease in $\mathrm{pH}$ may even be doubled due to the concurrent ocean warming that destabilizes gas hydrates and releases large amounts of methane, which, in turn, are respired by methanogenic bacteria to $\mathrm{CO}_{2}$ (Biastoch et al. 2011).

Manuscript received 13 February 2013; revised 1 November 2013; accepted 15 November 2013; final version received 12 December 2013. Corresponding Editor (ad hoc): T. P. Hurst.

${ }^{4}$ Corresponding author. E-mail: cclemmesen@geomar.de
Elevated $\mathrm{CO}_{2}$ concentrations can disturb the acidbase regulation, blood circulation, and respiration, as well as the nervous system of marine organisms, leading to long-term effects such as reduced growth and reproduction (Pörtner et al. 2004). Research on freshwater fish shows that early life stages such as eggs and larvae are more susceptible to acidification than are adults (Sayer et al. 1993), and it is hypothesized that this should apply to marine species as well. A plausible functional explanation is that fish are able to control their acid-base balance by bicarbonate buffering, mainly across the gills. However, embryos and early larvae use cutaneous gas exchange, since they often lack gills, as organogenesis is not yet completed, and therefore are restricted in their acid-base regulatory capacities. This may cause either direct acid-base imbalances in the organism which can lead to tissue damage, and/or reallocation of energy resources away from other vital processes such as growth or development. In a previous study, we found severe tissue damage to many internal organs in Atlantic cod larvae under elevated $\mathrm{CO}_{2}$ concentrations, coupled, however, with increased larval growth (Frommel et al. 2012). The question is whether these responses are unique to Atlantic cod, or whether other commercial fish species with different life-history strategies will react similarly to ocean acidification. Although the body of knowledge of the effects of elevated $\mathrm{CO}_{2}$ concentrations is growing, little attention has been paid to histological examination of tissue responses.

Our study species is Atlantic herring, a benthic spawner and schooling pelagic fish. It is also of high 
commercial importance with two-thirds of the populations currently overexploited and outside of the range defined as biologically safe (Thünen Institute of Baltic Sea Fisheries 2013). Herring are distributed throughout the North Atlantic shelf regions from the east coast of North America to the west coast of Europe and the Baltic Sea. They are characterized by distinct groups defined by spawning season and location (Geffen 2009). Especially in response to salinity clines, a significant genetic structuring of herring populations has been observed (Bekkevold et al. 2005, Limborg et al. 2012). Larval survival is an important factor determining yearclass strength in herring, especially in years of poor recruitment (Nash and Dickey-Collas 2005). Herring spawn in areas predicted to be severely affected by ocean acidification. $p \mathrm{CO}_{2}$ values above $0.4053 \mathrm{kPa}$ could be reached in the future at important herring spawning grounds in the Baltic Sea such as the Kiel Fjord (Melzner et al. 2012). At higher latitudes and along the Scandinavian coast, modeling studies predict a doubling of $p \mathrm{CO}_{2}$ and decreases in $\mathrm{pH}$ of $0.255-0.315$ units (Bellerby et al. 2005). We hypothesized that Atlantic herring larvae would be affected by elevated $\mathrm{CO}_{2}$ conditions similarly to Atlantic cod larvae. To test this, we reared Atlantic herring eggs to 39 days post hatch (dph) in the same large, outdoor mesocosms simultaneously with Atlantic cod larvae under two different future ocean acidification scenarios and today's levels. For further details on the experimental setup see Frommel et al. (2012) and Maneja et al. (2013a,b).

\section{Methods}

In this study, we exposed Atlantic herring larvae to three levels of $p \mathrm{CO}_{2}$ (control, $0.0385 \mathrm{kPa}$; medium, 0.183 $\mathrm{kPa}$; and high, $0.426 \mathrm{kPa}$ ) from newly fertilized eggs to 39 dph. Initially, the experimental design included a "low" treatment level of $0.0871 \mathrm{kPa} p \mathrm{CO}_{2}$, but this failed for technical reasons. Eggs and larvae were reared following a balanced randomized design of $p \mathrm{CO}_{2}$ levels in nine, land-based, replicated, outdoor mesocosms (2300 L, $1.5 \mathrm{~m}$ deep) at the University of Bergen's Marine Biological Station near Espegrend. Conditions for optimal survival were kept via a flow through of fresh seawater $(0.024 \pm 0.01 \mathrm{~L} / \mathrm{s}$ [mean $\pm \mathrm{SD}$ ], approximately replacing the entire water of each mesocosm in the course of a day) pumped from a 40 $\mathrm{m}$ depth and allowing for natural conditions such as temperature, salinity, and water quality (such as ammonia), in addition to the natural light cycle and intensity. Larvae were sampled for growth (standard length and dry mass), condition (RNA: DNA), and histological analysis.

\section{Fertilization and rearing}

Eggs from wild caught Norwegian Coastal herring (11 males and 11 females) were strip spawned onto $20 \times 20$ cm glass plates as "families" (crossing male 1 only with female 1 , male 2 with female 2 , etc.) and then placed in photo trays and fertilized with ambient and $\mathrm{CO}_{2}$-treated seawater. These glass plates were suspended by ropes at mid-depth in the mesocosm tanks. The tanks were aerated with fine bubbles in a ring from the bottom of the tanks. Oxygen, temperature, salinity, and $\mathrm{pH}$ levels were monitored daily (WTW Oxi 340i, WTW T-S cond $330 \mathrm{i}$, and WTW pH 340i with sentix $81 \mathrm{pH}$ probe, probe calibrated daily before use; all WTW WissenschaftlichTechnische Werkstätten GmbH, Weilheim, Germany). Shortly before hatching, the egg incubation plates were transferred into floating buckets with mesh bottoms (allowing for free gas exchange) inside the mesocosms. Peak hatch of the larvae occurred 23 days post fertilization in the floating buckets after approximately 135 degree days (the number of days multiplied by the temperature experienced). The hatched larvae were then placed into the replicated mesocosms, taking care to mix them proportionally from the different families using ladles to achieve an initial density of approximately 1.51.7 larvae/L in each tank (approximately 3400-3800 larvae/tank). Natural zooplankton from the fjord was continuously filtered through a size-selective filter system and collected for feeding to the larvae in the mesocosms (Seljeset et al. 2010). Each day, a subsample of the zooplankton remaining in each mesocosm was counted, and fresh zooplankton was added to achieve a prey density of 2000 zooplankton/L in all tanks. The larvae were first provided with zooplankton in the size range of $80-250 \mu \mathrm{m}$, and this range was increased to $350-500 \mu \mathrm{m}$ during the course of the experiment as the larvae grew larger (Folkvord et al. 2000).

\section{Seawater manipulation}

Three replicate mesocosms were maintained at each of the three $\mathrm{pH}$ levels (control, 8.08; medium, 7.45; and high, 7.07; measured on the total scale) by dissolving pure $\mathrm{CO}_{2}$ into the water with fine diffusers in the treatments (medium and high), while the control was left to fluctuate freely at ambient conditions without manipulation but with close monitoring. The addition of $\mathrm{CO}_{2}$ was controlled by two mobile computers (Aquastar, iks ComputerSysteme $\mathrm{GmbH}$, Karlsbad, Germany) that regulated the diffusion of $\mathrm{CO}_{2}$ from a gas cylinder into the mesocosms via a feedback loop with $\mathrm{pH}$ probes (iks glass electrode, article number 001023, iks ComputerSysteme $\mathrm{GmbH}$ ) connected to magnet valves. The $\mathrm{pH}$ in each of the tanks was measured at 15-min intervals, adding $\mathrm{CO}_{2}$ on demand. The $\mathrm{CO}_{2}$ diffuser was connected to the water inflow at the bottom of the tank, and, together with the aeration via the bubble ring, this insured that there was rapid mixing and a homogeneous water $\mathrm{pH}$. In addition to the $\mathrm{pH}$ measurements from the system, the $\mathrm{pH}$ was measured daily with a laboratory-grade glass $\mathrm{pH}$ probe (WTW pH 340i, WTW Wissenschaftlich-Technische Werkstätten $\mathrm{GmbH}$ ) calibrated with a seawater standard and certified reference material (oceanic carbon dioxide quality control; obtained from Andrew G. 
Dickson, Scripps Institution of Oceanography). We initially included a "low" treatment level of $0.0871 \mathrm{kPa}$ $p \mathrm{CO}_{2}$ (pH 7.7) that failed for technical reasons. This level of $p \mathrm{CO}_{2}$ stimulates phytoplankton growth and may have been triggered by a phytoplankton bloom, elevating the $\mathrm{pH}$ of the water above the threshold $\mathrm{pH}$ and triggered the addition of excessive $\mathrm{CO}_{2}$ to the tanks. The extent of the $\mathrm{pH}$ drop ( $2 \mathrm{pH}$ units) and the speed of the drop (within 12 hours) rules out biological issues and can only be accounted for by mechanical error.

Once each week, water samples were collected for dissolved inorganic carbon (DIC) and total alkalinity (TA) measurements in order to calculate actual $\mathrm{CO}_{2}$ values in the water (Pierrot et al. 2006). The mean values over the course of the experiment for dissolved inorganic carbon were $2106.5 \mu \mathrm{mol} / \mathrm{kg}$ seawater (SW) for control, $2330.6 \mu \mathrm{mol} / \mathrm{kg} \mathrm{SW}$ for the medium, and $2471.8 \mu \mathrm{mol} /$ $\mathrm{kg} \mathrm{SW}$ for the high treatment. Total alkalinity for the control treatment was $2282.3 \mu \mathrm{mol} / \mathrm{kg} \mathrm{SW}, 2287.5 \mu \mathrm{mol} /$ $\mathrm{kg} \mathrm{SW}$ for the medium, and $2290.7 \mu \mathrm{mol} / \mathrm{kg} \mathrm{SW}$ for the high treatment. This resulted in mean $p \mathrm{CO}_{2}$ levels of $0.0365 \mathrm{kPa}$ for the control, $0.1906 \mathrm{kPa}$ for the medium, and $0.4313 \mathrm{kPa}$ for the high treatment. Mean calculated $\mathrm{pH}$ values were 8.08 for the control, 7.45 for the medium, and 7.08 for the high treatment tanks. (More details on the carbonate chemistry are given in Maneja et al. [2013a]). Temperature at the start of the experiment in March was $5^{\circ} \mathrm{C}$ and reached $10^{\circ} \mathrm{C}$ when the experiment was terminated in May, while the salinity remained at a mean of 33.3. Oxygen was measured daily with a handheld oxygen probe (WTW Oxi 340i) and consistently remained above $90 \%$ saturation.

\section{Sampling}

Forty fish from each tank were sampled each week using a cylindrical tube that reached to the bottom of the mesocosm in order to sample larvae over the entire water column. Three weeks into the experiment, the larvae were able to avoid the cylinder, and the fish had to be sampled using large plastic ladles in addition to the tube in order to catch enough larvae. Twenty larvae per tank were photographed live for morphometrics and staging, and they were shock-frozen on dry ice and stored at $-80^{\circ} \mathrm{C}$ for future analyses. Larvae collected for histological examination (10 per tank) on two sampling days were preserved in $4 \%$ buffered formaldehyde. Samples for histological analysis were taken on $25 \mathrm{dph}$ and 39 dph, RNA: DNA ratios were determined at 32 $\mathrm{dph}$ and at $39 \mathrm{dph}$ to evaluate larval fish condition at a time period where changes in the organ structure were expected (Frommel et al. 2012). The remaining larvae were used for otolith analyses. At the termination of the experiment, all tanks were drained and the remaining larvae sampled.

\section{Morphometrics and staging}

The standard lengths of the larvae were determined from the photographs using image analysis software
(ImagePro Plus, WEISS Imaging and Solutions $\mathrm{GmbH}$, Bergkirchen/Günding, Germany). The larvae were then staged according to the developmental key by Doyle (1977) by looking at the degree of the flexion of the notochord and the differentiation of the dorsal fin. The distribution of larval developmental stages was then contrasted across treatments at each sampling date and larval age, and then related to critical developmental landmarks (Fig. 1).

\section{RNA : DNA determination}

RNA: DNA ratios are good estimates of relative condition, due to the fact that while DNA content is stable in the cell, the RNA content varies with the nutritional state of the larvae. All larvae were freeze dried for 16 hours (Christ Alpha 1-4 freeze dryer, Martin Christ Gefriertrocknungsanlagen $\mathrm{GmbH}$, Osterrode, Germany) and weighed (dry mass [DM]; Sartorius SC 2 microbalance, Sartorius AG, Göttingen, Germany; precision $\pm 0.1 \mu \mathrm{g}$ ). Measurements of RNA and DNA were made using the fluorometric method described by Clemmesen (1993) and modified by Belchier et al. (2004) with slight adjustments. Larvae were freeze dried, decapitated, and the muscle tissue was homogenized in $400 \mu \mathrm{L}$ or $800 \mu \mathrm{L} 0.01 \%$ sodiumdodecyl sulfate (TESDS) buffer, depending on the dry mass. When necessary, the homogenate was diluted up to 10 -fold with $0.01 \%$ TE-SDS. Ethidium bromide was used as a specific nucleic acid fluorescent dye for both RNA and DNA, and the total fluorescence was measured (Fluoroskan Ascent, Thermo Scientific, Waltham, Massachusetts, USA). RNAse was then used to digest all RNA enzymatically. The RNA fluorescence was calculated by subtracting the DNA fluorescence from the total fluorescence. By using the calibration curve fitted to the standard measurements (23 s r RNA Boehringer, Boehringer Ingelheim $\mathrm{GmbH}$, Ingelheim am Rhein, Germany, $R^{2}=0.99$ ), the amount of RNA was calculated. Following Le Pecq and Paoletti (1966), the DNA concentration was calculated using the relationship between RNA and DNA fluorescence with a slope ratio of standard DNA to standard RNA of 2.2, which adjusts for the relative fluorescence intensity difference of RNA and DNA.

\section{Histopathology}

Formalin fixed samples were blocked up in 2hydroxymethyl-methacrylate (HEMA) following dehydration in $50 \%, 70 \%$, and $95 \%$ ethyl alcohol and stained in Lee's methylene blue/basic fuchsin (Bennett et al. 1976) for general structure and Alcian blue/PAS (Bancroft and Stevens 1975) for acid and neutral muco-substances. The herring larvae for these observations were sampled on $25 \mathrm{dph}$ and $39 \mathrm{dph}$ only and were sectioned whole in either a longitudinally horizontal or lateral plane depending on whether they had been fixed straight or curved. Possible effects on all tissues, including the gills, skin, and skeleton (backbone), were 


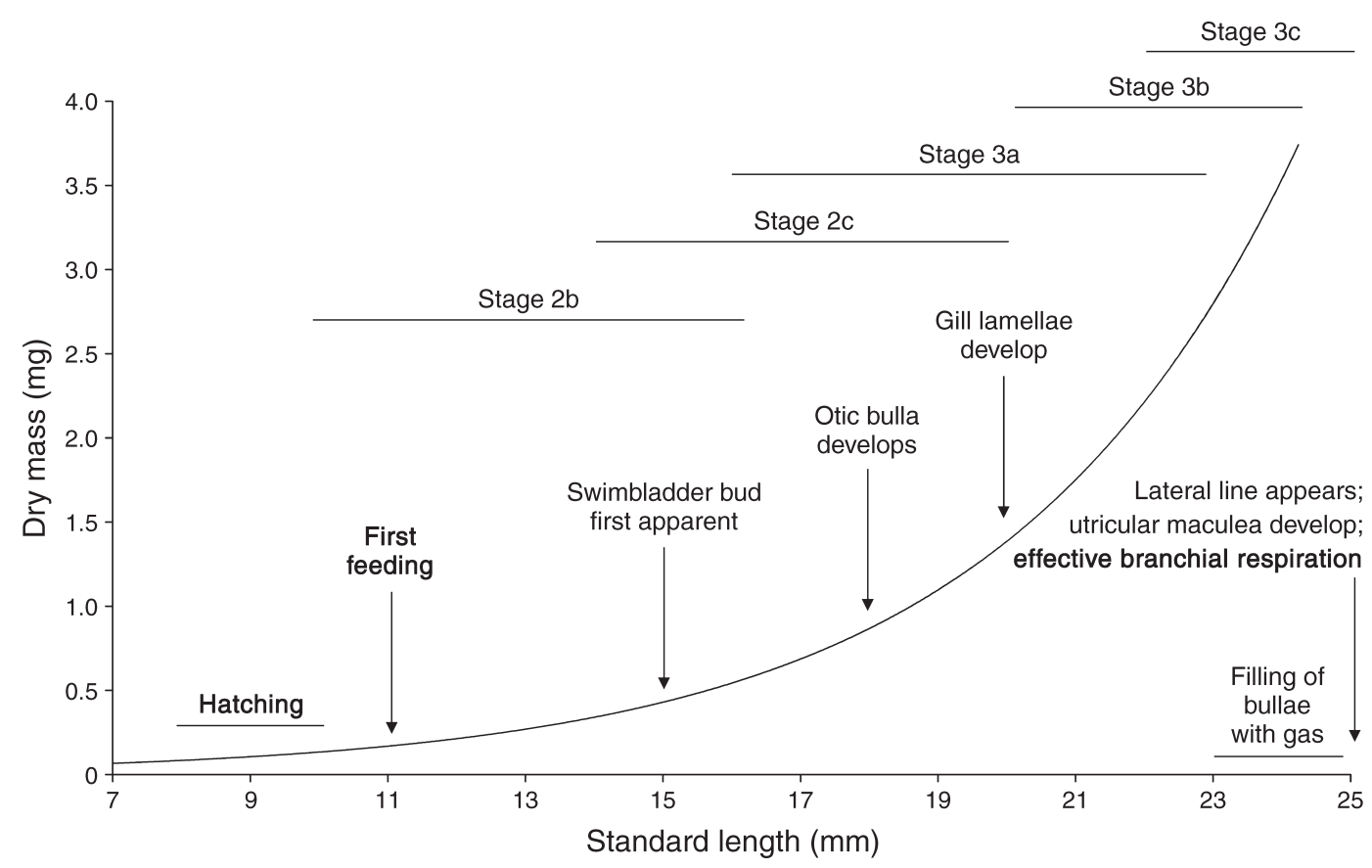

FIG. 1. Developmental stages of herring larvae in relation to size, including critical landmarks in boldface type: hatching, first feeding, and switch from cutaneous to branchial respiration. Compiled from Allen et al. (1976), Blaxter et al. (1983), and de Silva (1974). Data on developmental stages from this study are included.

considered in the analysis. However, changes to major organs associated with metabolic control (i.e., liver, kidney, and pancreas) received particular attention. Damage was measured via stereology, and each organ was scored as to its degree of severity by an observer blind to the experimental treatment from which the tissue was derived. Stereology is a quantitative technique based on systematic and randomized sampling for the interpretation of two-dimensional histological sections from three-dimensional material, and it is a powerful tool for analysis of tissue and organ development/ condition in fish larvae (Hill et al. 2002).

\section{Data analysis}

Assumptions of normality and homogeneity of variance were confirmed using Kolmogorov-Smirnoff and Levene's tests. Due to low replicate size, classical statistics are limited; therefore, an additional statistical analysis using $95 \%$ confidence intervals around statistical effect sizes (Nakagawa and Foster 2004) was used to verify the results shown by random effect mixed model nested ANOVA analyses. This can provide further information to be included into a metaanalysis such as the one by Kroeker et al. (2010). Therefore, the effect of treatment for different parameters was analyzed by effect size analysis, which calculates the natural logarithm of the response ratio ( $\ln \mathrm{RR}$ ) of the mean effect of a treatment to the mean of the control, along with the variance and the $95 \%$ confidence intervals using the tank means (see Hedges and Olkin 1985, Kroeker et al. 2010). Response ratios allow quantification of the change arising from manipulation proportional to the control group in experiments. In experimental studies, Intransformed response ratios are commonly used, as they are statistically robust and facilitate interpretation in a biological context (Hedges and Olkin 1985). Histological data was analyzed using the PERMANOVA (Primer 6, PRIMER-E Ltd., Lutton, UK) data analysis package for a nonparametric multivariate treatment comparison. This approach is based on similarity matrices, makes no assumptions about data distribution, and estimates test statistics through permutations. It is especially useful for analyses of data sets that include different data types.

\section{RESUlts}

Larval growth measured by change in dry mass (Fig. 2) and standard length (Fig. 3) was significantly reduced at elevated $p \mathrm{CO}_{2}$, with the difference increasing with time. Random effects mixed model nested ANOVA with tank as random factor, treatment as category, and time as continuum factor was analyzed for dry mass, standard length, and RNA : DNA of the herring larvae. Age of the larvae (dph), treatment, and the interaction between dph and treatment significantly affected the dry mass (mixed model ANOVA for dry mass, dph $P<$ $0.0001, F_{1,380}=520.37$, sum of squares $[\mathrm{SS}]=44.33$; treatment, $P<0.0001, F_{2,380}=13.88, \mathrm{SS}=2.36$; dph $\times$ treatment, $\left.P<0.0001, F_{2,380}=25.84, \mathrm{SS}=4.40\right)$ and standard length of the herring larvae (mixed model ANOVA for standard length, dph $P<0.0001, F_{1,963}=$ 4133.5, $\mathrm{SS}=7843.1$; treatment, $P<0.0001, F_{2,963}=$ 


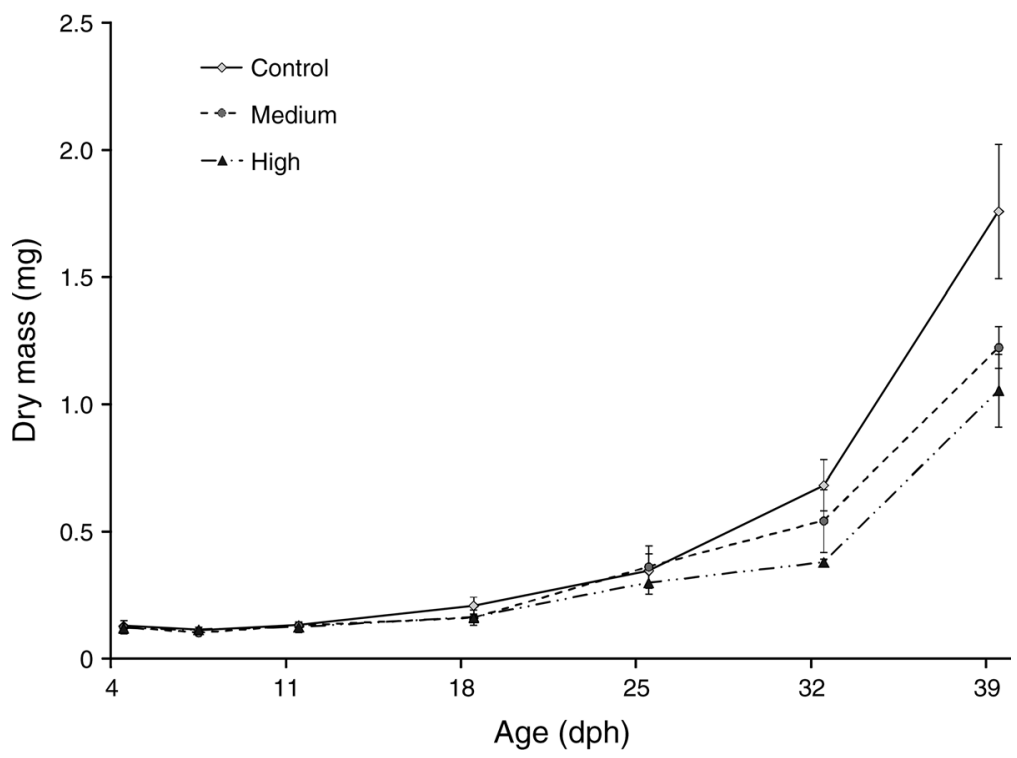

FIG. 2. Dry mass (mean and standard deviation) for each of the three treatment levels of partial pressure of $\mathrm{CO}_{2}$ gas $\left(p \mathrm{CO}_{2}\right.$; control, medium, and high) over the entire experimental period (days post hatch [dph]). $N=10-15$ larvae per tank and $30-45$ larvae per replicate.

41.76, $\mathrm{SS}=158.5 ; \mathrm{dph} \times$ treatment, $P<0.0001, F_{2,963}=$ 30.93, SS = 117.37). Mixed model ANOVA using RNA : DNA ratios resulted in a significant effect of treatment, but no effect of age $(\mathrm{dph})$ or the interaction of age and treatment (mixed model ANOVA for RNA : DNA, dph $P=0.149, F_{1,83}=2.12, \mathrm{SS}=1.62$; treatment, $P=0.0067, F_{2,83}=5.32, \mathrm{SS}=8.13$; dph $\times$ treatment, $P=0.5482, F_{2,83}=0.60, \mathrm{SS}=0.92$ ).

Calculated effect sizes and $95 \%$ confidence intervals around effect sizes for dry mass and standard length of the medium vs. the control and the high vs. the control treatment are shown in Figs. 4 and 5. At 39 dph, herring larvae from the medium treatment had 30\% $\pm 13 \%$ (mean $\pm \mathrm{SD}$ ) less dry mass than did the control, while the high treatment had $40 \% \pm 14 \%$ less dry mass than did the control (Fig. 4). For standard length, herring larvae at 39 dph from the medium treatment had a $6 \% \pm 3 \%$ lower standard length than did the control, while the high treatment showed a $10 \% \pm 6 \%$ lower standard length than did the control (Fig. 5). Similarly, RNA: DNA ratios were reduced with increasing $\mathrm{CO}_{2}$ treatment and time, with the medium treatment being $7 \% \pm 11 \%$ lower than the control and the high treatment $10 \% \pm 7 \%$ lower than the control treatment (Fig. 6). Along with reduced growth and condition in the $\mathrm{CO}_{2}$ exposed larvae, a decrease in relative age was observed. There were no treatment differences in the development of the larvae up to $32 \mathrm{dph}$. However, at $39 \mathrm{dph}$, the larval development stages diverged between treatments, varying between $2 \mathrm{c}$ and 3c (see Fig. 7) with significantly more larvae in the control treatment at later development stages, compared to the medium and the high treatment (ANOVA, $P<$ $0.005, F_{2,59}=40.3$; Fig. 7).
There was proportionally a greater incidence of larvae with histological evidence of organ damage at $25 \mathrm{dph}$ than at $39 \mathrm{dph}$ (Fig. 8). Significant treatment-related damage was found at $25 \mathrm{dph}$ (PERMANOVA, $P=$ $0.023, F_{2,29}=37.75$, mean square $\left.[\mathrm{MS}]=8894.4\right)$ with no significant tank effect $\left(P=0.849, F_{2,11}=0.530, \mathrm{MS}=\right.$ 226.5). The affected tissues included internal organs such as the kidney, pancreas, and liver, as well as the external structures of the fins. At $39 \mathrm{dph}$, there was no significant effect of $\mathrm{CO}_{2}$ treatment on the tissues (PERMANOVA, $P=0.979, F_{2,9}=0.115$, $\mathrm{MS}=179.6$; Fig. 8). Damage to the liver was mainly in the form of enlarged lipid vacuoles that increased in number with

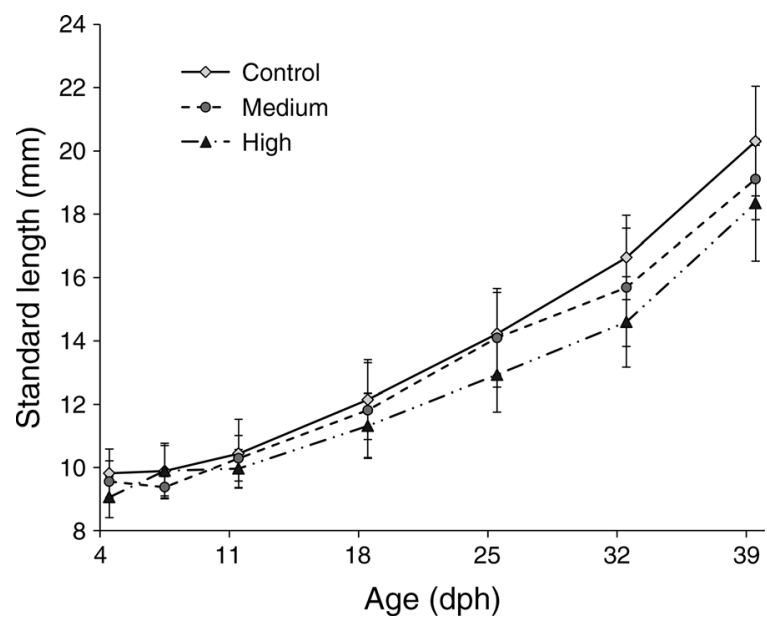

FIG. 3. Standard length (mean and standard deviation) for each of the three treatments over the entire experimental period. $N=20$ larvae per replicate and 60 larvae per treatment. 


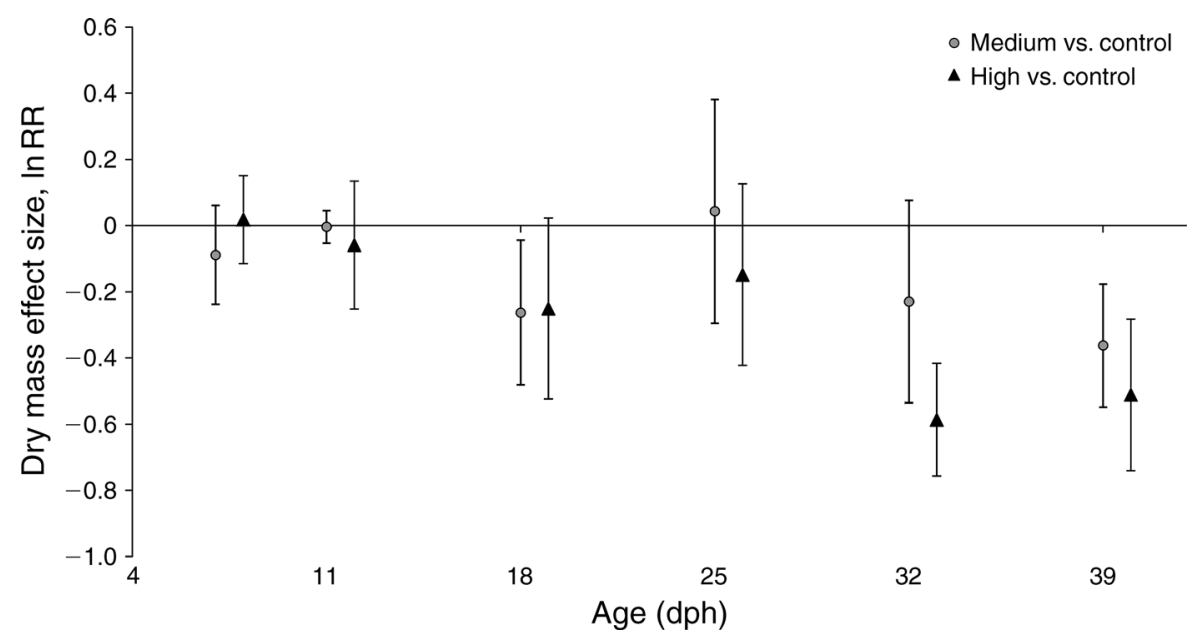

FIG. 4. Effect sizes (natural logarithm of the response ratio, ln RR) and $95 \%$ confidence intervals for dry mass of herring larvae at different ages. Data presented are based on the differences between medium vs. control and high vs. control treatment.

increasing $\mathrm{CO}_{2}$ concentration. More than $50 \%$ of $25 \mathrm{dph}$ larvae in the medium and high treatments were determined to have damage scores 2 or 3 , based on these enlarged lipid vacuoles. Vacuolation of the kidney tubule epithelial cells was present, leading to a loss in structural integrity of the pronephric tubules and cellular atrophy. Over $60 \%$ of the 25 dph larvae in the medium and high treatments were determined to have damage scores of 3 to 5 , based on the presence of these vacuoles and their size (Fig. 8 and Table 1). In larvae from the high $\mathrm{CO}_{2}$ treatment, some of the neck cells of kidney tubules also stained darker and showed signs of breaking up (Fig. 9). Damage to the pancreas consisted of vacuolation (damage scores 3-5) and degeneration (damage score 6), plus alterations to tissue architecture whereby the normal pyramidal exocrine cells sitting on a well-defined basement membrane were replaced by rounded cells on an irregular basement membrane. The rosettes of the acini that form around zymogen granules were also absent. In addition to internal organs, damage to the fins was found in $10-20 \%$ of the $25 \mathrm{dph}$ larvae from the medium and high treatments, in the form of abnormal structure of the bone and cartilage, as well as enlarged tissue structure around the bone (Fig. 9). No abnormalities were found in the heart tissue, primary gill structures, or skeleton (backbone).

Besides roughly counting larvae into each tank, we also counted the number of hatched, live, dead, and unfertilized eggs on the glass plates when they were removed from the tanks to check our starting numbers. There was no indication of catastrophic mortality during the experiment and no significant difference in mortality rates among $\mathrm{CO}_{2}$ treatments. Average survival rates were high, with daily survival rates above 0.9 for all of the tanks. This is in keeping with patterns that we see using these experimental methods in our system based on natural plankton (Vollset et al. 2009, Seljeset et al. 2010).

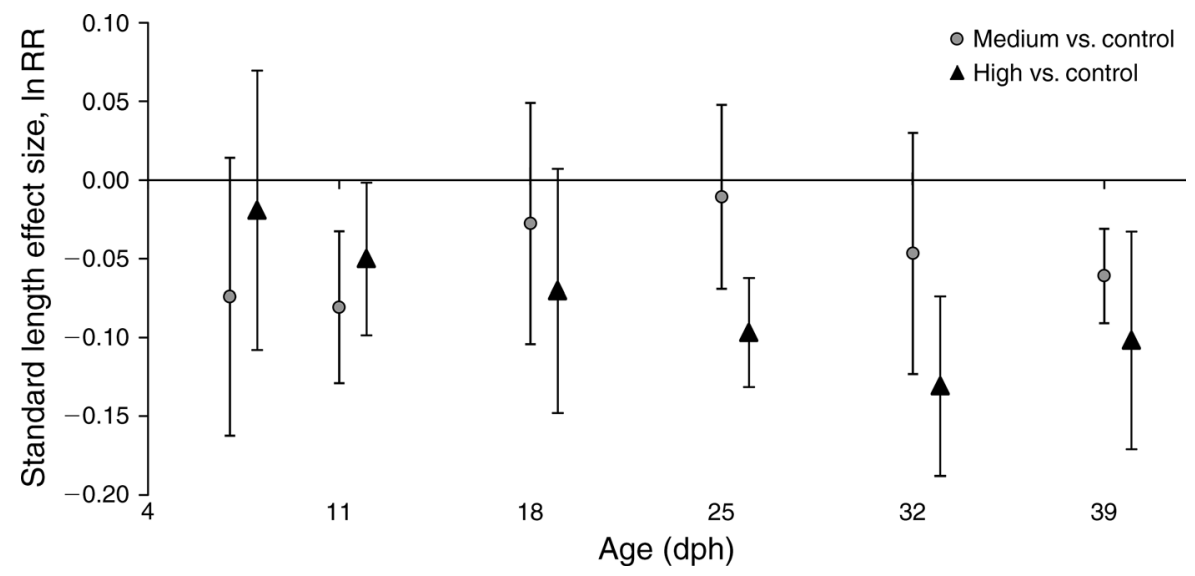

FIG. 5. Effect sizes and $95 \%$ confidence intervals for standard length of herring larvae at different ages. Data presented are based on the differences between medium vs. control and high vs. control treatment. 


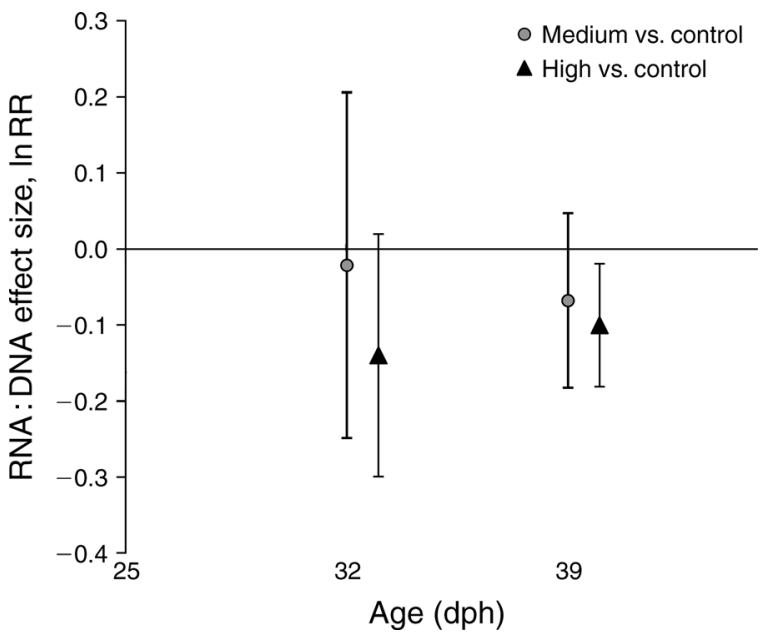

FIG. 6. Effect sizes and $95 \%$ confidence intervals for RNA : DNA ratios of herring larvae at 32 and $39 \mathrm{dph}$. Data presented are based on the differences between medium vs. control and high vs. control treatment.

\section{Discussion}

Our data collected on herring larvae grown in open air mesocosms revealed increased levels of morphological and physiological abnormalities under simulated ocean acidification. In particular, the reduction in growth rate both in terms of size and age-at-development in each stage can have severe consequences for the larvae. Early life-history stages are subject to very high rates of mortality (Bailey and Houde 1989), selectively acting on the smaller and slower growing larvae within an age class (Meekan et al. 2006). Thus the effect of $\mathrm{CO}_{2}$ leading to smaller larvae will consequently extend the predation window for a longer period and therefore could lead to fewer larvae reaching the next developmental stage. Furthermore, growth is a critical factor for survival because of match-mismatch with larval zooplankton prey (Cushing et al. 1990) and matching oceanographic situations, as well as the timing of metamorphosis (Iles and Sinclair 1982, Sinclair and Tremblay 1984). Lower RNA: DNA ratios in $\mathrm{CO}_{2^{-}}$ exposed larvae further demonstrate lowered nutritional condition and growth potential (Buckley et al. 2008, Huwer et al. 2011) suggesting carry-over effects throughout development.

The reduction in growth could be due to the observed decrease in zymogen granules of the exocrine acinar cells in the pancreas. With its endocrine-exocrine role the pancreas is central to organ development and growth. Depending on whether they have a lipid- or glycogenbased metabolism, the presence of small lipid vacuoles in hepatocytes of some fish species is normal. However, the presence of enlarged lipid vacuoles in hepatocytes such as those observed in these studies can be the result of a failure in the lysosomal vascular system leading to lysosomal dysfunction, a response found in fish from chemically polluted areas (Köhler 1991, Lowe et al.
1992). So-called fatty degeneration is an adaptive response to stress and indicates reduced functionality. Likewise, the atrophy exhibited in the kidney tubules infers reduced functionally, especially when combined with the presence of vacuolated regions within the cells. Cellular and tissue atrophy following exposure to chemical pollution can be the result of an increase in protein breakdown, a decrease in protein synthesis, or membrane damage, notably lysosomal, leading to cellular dysfunction (Lawrence 2003). Insomuch as they are responsible for maintaining homeostasis of body fluids and excretion, any failure or impairment of kidney function can have severe consequences for the organism. This is particularly true in early life stages, as they are one of the key sites for ion regulation before the onset of functional gills.

The stages at which most organ damage was observed correlate with a phase of energy-costly processes taking place in the larvae, mainly linked to the switch from cutaneous to branchial respiration (Fig. 1). At elevated $\mathrm{CO}_{2}$ conditions, the larvae remained longer in these stages (Fig. 7). The development of the circulatory system and respiratory vascular apparatus, as well as the use of respiratory pigments, happens late in the development of herring larvae at metamorphosis. Additionally, gills are not present until a larval length of above $20 \mathrm{~mm}$ (de Silva 1974), a size that was only reached in the control group at $39 \mathrm{dph}$. Therefore, most of the larvae in our study depend on cutaneous gas exchange, and this leaves them vulnerable, since the absence of accessory and osmoregulatory structures suggests a less efficient acid-base regulation system. It could be speculated that the energy needed for efficient cutaneous acid-base regulation leads to a decrease in energy available for growth, leading to significantly smaller and less developed larvae in the treatment groups than in the control fish. Studies comparing growth, development, and metabolic rate in sea urchin

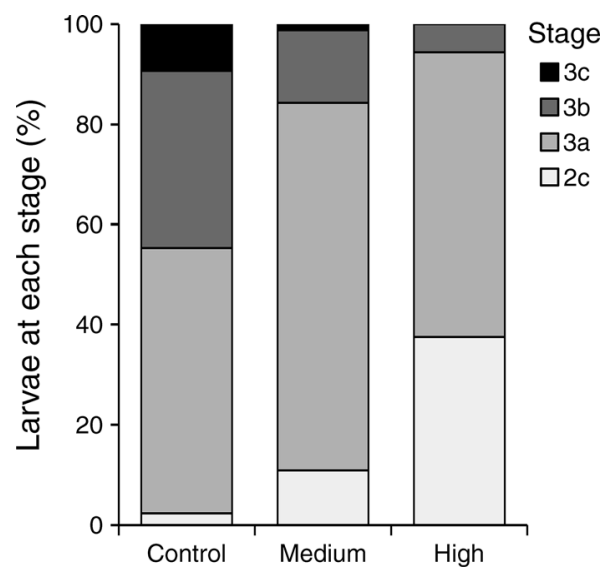

Fig. 7. Percentage of larvae at various stages of development (Doyle 1977) $39 \mathrm{dph}$ for each of the three treatment levels (control, medium, and high). $N=30$ larvae per tank and $N=90$ larvae per treatment. 

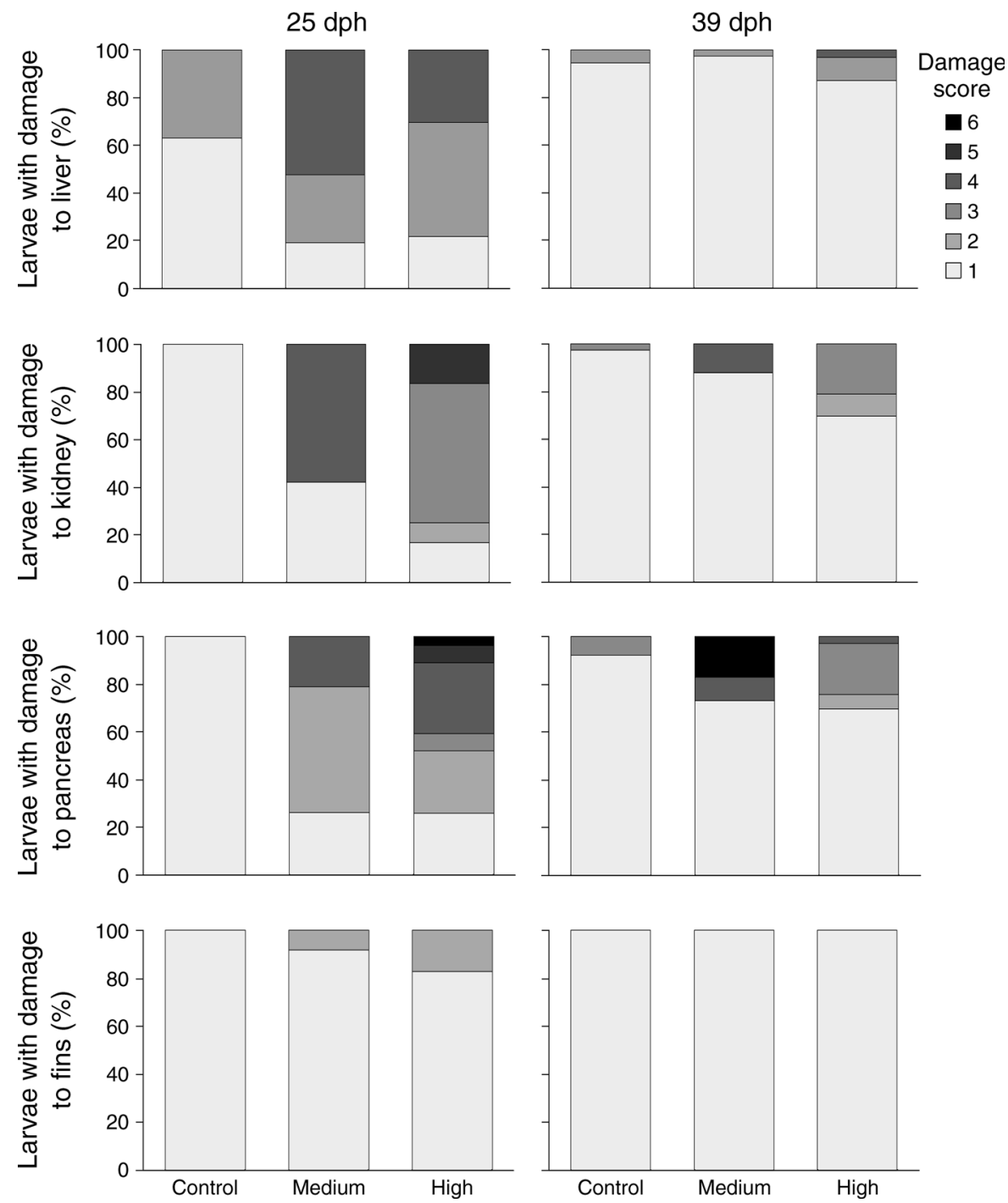

FIG. 8. Percentage of larvae at 25 and 39 dph displaying different degrees of tissue damage (liver, kidney, pancreas, and fins) in each treatment level (control, medium, and high treatment). Severity of damage increases with increasing score (1 is no damage) and shading. See Table 1 for a description of damage scores. $N=21-44$ larvae per treatment.

(Strongylocentrotus purpuratus) showed a greater energy demand in the $\mathrm{CO}_{2}$-treated animals compared to the control group (Stumpp et al. 2011). In addition to the kidney, acid-base regulation in the larvae is achieved via highly specialized chloride cells, or mitochondrial-rich cells. These cells are located on the yolk sac in herring embryos as early as three days post fertilization
(Bodenstein 2012), changing their distribution over the body surface during larval development (Wales and Tytler 1996) to be concentrated on the gills of juveniles and adults (Hwang and Lee 2007). A decrease in chloride cell abundance, distribution, and size has previously been documented as a mechanism to cope with ionic stress (Hiroi et al. 1999, Kikkawa et al. 2002).

TABle 1. Damage scores in Fig. 8.

\begin{tabular}{clll}
\hline \hline Damage score & Liver, tissue score 2 & \multicolumn{1}{c}{ Kidney, tissue score 3 } & Pancreas, tissue score 2 \\
\hline 1 & normal & normal & normal \\
2 & vacuoles moderate & atypical structures & atypical, irregular, atrophic tissue \\
3 & vacuoles abundant & vacuoles present & atypical \\
4 & & atypical structures and vacuoles & atypical structures and vacuoles \\
5 & & large vacuoles & vacuoles moderate \\
6 & & & degenerated tissue \\
\hline
\end{tabular}



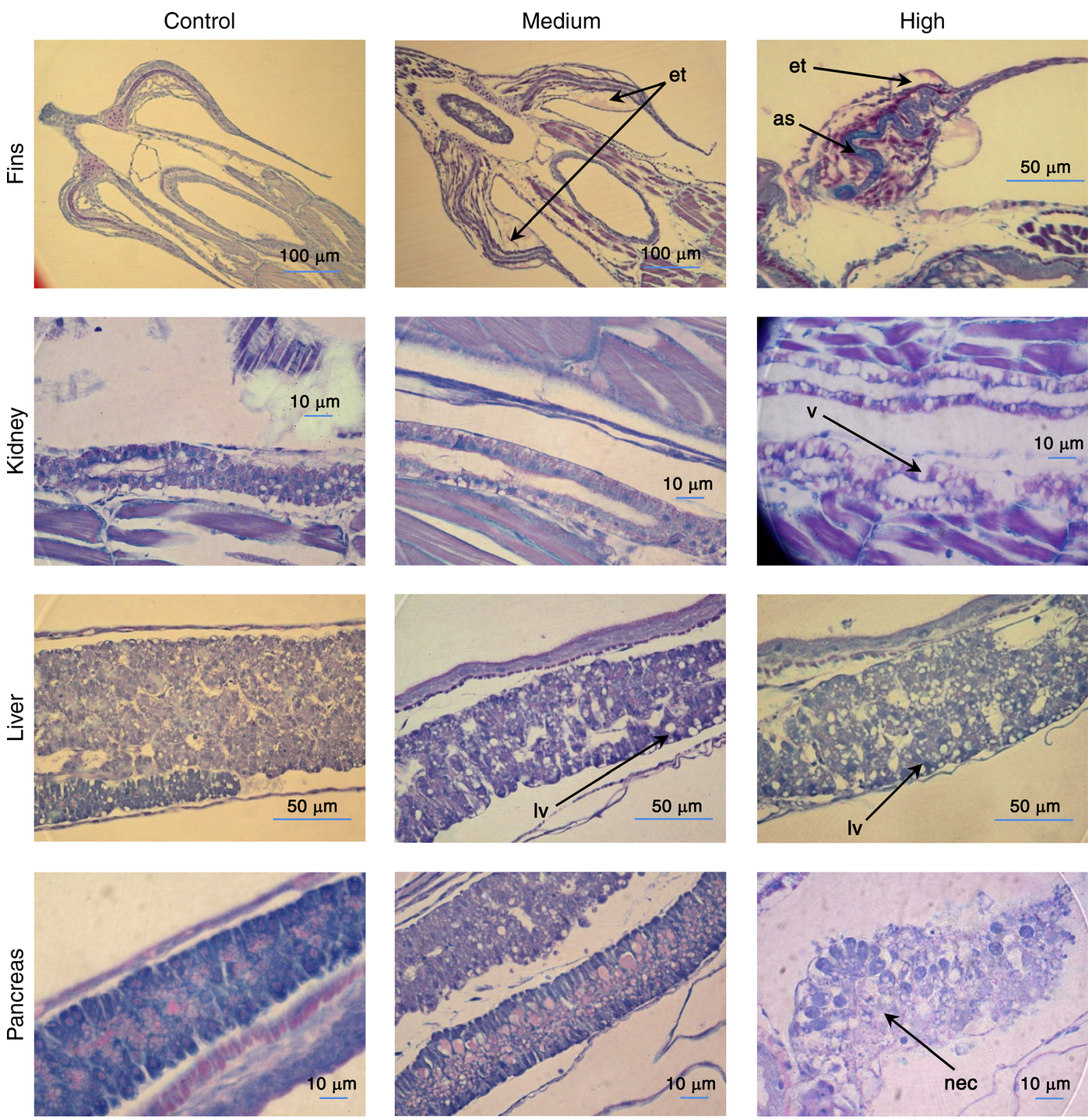

FIG. 9. Histological sections of different organs of herring larvae at three different $p \mathrm{CO}_{2}$ treatment levels. Observed tissue alterations for fins are enlarged soft tissue (et) and abnormal bone and cartilage structure (as). Observed tissue alterations for kidney are vacuolated epithelial cells (v). Observed tissue alterations for liver are enlarged lipid vacuoles (lv). Observed tissue alteration for pancreas is cellular necrosis (nec).

However, this response was not found in Baltic herring embryos reared at $\mathrm{CO}_{2}$ concentrations up to $0.4053 \mathrm{kPa}$ (Bodenstein 2012).

Previous studies on the effects of ocean acidification on herring are limited to embryonic development in the Baltic population. While these studies found no effect on growth, embryogenesis, or hatch success (Franke and Clemmesen 2011, Bodenstein 2012), elevated $\mathrm{CO}_{2}$ concentrations around $0.4053 \mathrm{kPa}$ were found to double the mortality rate of embryos from fertilization to hatch (Bodenstein 2012) and lead to a decrease in condition
(RNA:DNA) in newly hatched larvae (Franke and Clemmesen 2011).

Many of the responses observed in the Atlantic herring larvae are similar to those reported for the Atlantic cod larvae co-reared in the same system (Frommel et al. 2012a). There are important differences however, and it is interesting to compare these two species, as they have very different life history characteristics. Cod eggs are pelagic, while herring lay adhesive benthic eggs. Thus, these two species should encounter very different hydrographic conditions during egg 
development, with bottom waters often depleted of oxygen and enriched in $\mathrm{CO}_{2}$, while surface waters are aerated. Yet, in both species, severe organ damage under ocean acidification scenarios was observed at similar developmental stages. While the internal organs were affected similarly in both species, damage to the fins was only found in herring. Also, the cod larvae increased in growth under elevated $\mathrm{CO}_{2}$ conditions, but size-atdevelopmental stage was not affected by treatment, while exposed herring larvae were smaller than the control and slower in development as could be shown by the differences in developmental stages.

The present study confirms the negative effects of high $\mathrm{CO}_{2}$ concentrations on developmental processes, organ damage, and growth found in other temperate (Baumann et al. 2012, Frommel et al. 2012) and tropical fish species (Munday et al. 2009a). The $p \mathrm{CO}_{2}$ treatment levels (except for the aborted low treatment) exceed the generally predicted concentrations and represent worstcase scenarios expected in high latitudes and under upwelling conditions. These concentrations are higher than in most of the studies cited here.

Other effects of $\mathrm{CO}_{2}$ on marine fish include hypercalcification of otoliths and disrupted behavior patterns. An increase in otolith size in relation to increases in $\mathrm{CO}_{2}$ was found in temperate fish such as sea bass larvae (Checkley et al. 2009), newly hatched herring larvae (Franke and Clemmesen 2011), juvenile walleye pollock (Hurst et al. 2012), and cod larvae (Maneja et al. 2013b) as well as in tropical fish such as clownfish larvae (Munday et al. 2011b) and cobia (Bignami et al. 2013b). A change in otolith size and density may affect the auditory sensitivity and perception in the larvae (Bignami et al. 2013a). Sensory and cognitive impairment in respect to homing behavior (Munday et al. 2009b, Devine et al. 2011), prey detection (Cripps et al. 2011), predator avoidance (Dixson et al. 2010, Munday et al. 2010), and risk assessment (Ferrari et al. 2012) has been observed in coral reef fishes and has been linked to effects of $\mathrm{CO}_{2}$ on neurotransmitter functions in the brain (Nilsson et al. 2012). Behavioral changes including boldness, exploratory behavior, lateralization, and learning were recently also documented in a temperate fish, the three-spined stickleback (Jutfelt et al. 2013).

There are however a number of studies that have found no significant effect of elevated $\mathrm{CO}_{2}$ conditions on development, growth, survival, otoliths, or behavior (Munday et al. 2009c, 2011a, b, Franke and Clemmesen 2011, Frommel et al. 2013, Hurst et al. 2013). An explanation for the observed differences between the studies could be the shorter duration compared to the experiment presented here. It is possible that effects of ocean acidification are not evident until later stages of development. Another explanation could be the environmental conditions of the study location. Fish populations that already experience a high variability in $\mathrm{CO}_{2}$ concentrations may naturally be adapted to increased $\mathrm{CO}_{2}$, and thus their larvae may be more robust. Recent work on oysters and coral reef fishes has demonstrated that the sensitivity of early life stages to elevated $\mathrm{CO}_{2}$ levels may be affected by the parental environment. Exposure of the parents to high levels of $\mathrm{CO}_{2}$ was shown to moderate the negative effects of $\mathrm{CO}_{2}$ on the offspring (Parker et al. 2011, Miller et al. 2012, Parker et al. 2012) with population specific differences (Parker et al. 2011). Similarly, trans-generational acclimation to increasing temperatures has recently been demonstrated for tropical reef fishes (Donelson et al. 2011). The experiment on walleye pollock (Hurst et al. 2012) used larvae from parents caught in the Puget Sound, an area with a naturally high variability in $\mathrm{CO}_{2}$ (Feely et al. 2010).

Similarly, Baltic cod (Frommel et al. 2013) and herring (Franke and Clemmesen 2011) come from areas with high variability and higher mean $\mathrm{CO}_{2}$ levels than the mean values observed in the oceans. The Boknis Eck monitoring station gives a 1986-1995 mean $p \mathrm{CO}_{2}$ level $>0.203 \mathrm{kPa}$ during the summer months when older herring larvae occur in the system (Melzner et al. 2012). In the Bornholm Basin, a major spawning area for cod in the Baltic, $\mathrm{pH}$ values down to 7.2 have been observed during the spawning period (Frommel et al. 2013). Decadal and seasonal variability in $\mathrm{pH}$ levels from 1960 to 2010 analyzed by von Dewitz (2012) confirmed pH values as low as 7.2 in the Bornholm Basin.

Clear evidence for the link between environmental and biotic factors in terms of temperature has been demonstrated for cod. While recruitment in some stocks is predicted to increase with temperature, others decrease, and again others are not affected at all (Drinkwater 2005).

Therefore, differences in the reaction to ocean acidification must be expected not only from different species, but also from different stocks of the same species, depending on the environment they actually experience. Additionally, changes in the production of lower trophic levels and changes in the biochemical composition in the food web have been found as a response to OA (Rossoll et al. 2012) and may indirectly affect larval fish by decreasing the quantity and quality of food organisms.

An analysis of studies on fish larvae and juveniles indicates that sensitive and more robust species exists. This could potentially lead to winners and losers, who will either suffer or benefit from the change in the environmental situation. For example, the antipredatory behavior of coral reef fish shows striking differences between species in the sensitivity to $\mathrm{CO}_{2}$, although the fish share very similar life history and ecological traits (Ferrari et al. 2011). But differences in the reaction to OA are not only found in the extent but also the mode of reaction to OA between species. Bignami et al. (2013a) predict differences in the sound reception in cobia larvae based on an otolith hearing model, whereas behavioral studies performed on larval Atlantic cod using swimming kinematics have shown that Atlantic cod larvae 
seem rather resilient to increased $\mathrm{COO}_{2}$, despite a significant difference in otolith growth (Maneja et al. $2013 a, b)$. Further studies should be performed using older fish and applying the behavioral approaches used for coral reef fish.

At present it is impossible to generalize the effects of OA on fish larvae, probably because of the diversity in the actual mechanisms of action on developmental processes and early life history traits. Whether species will be able to adapt to the rapidly changing climatic conditions is still uncertain (Merilä 2012). Herring, with their wide range of distribution, different and large population sizes, and relatively short generation could benefit through rapid adaptation (Geffen 2009). Indications for the possibility of local adaptation have been shown by Limborg et al. (2012) and Lamichhaney et al. (2012), comparing genes responsible for environmental adaptation in different herring stocks in the Baltic, North Sea, and North Atlantic. However, herring populations experience high fishing mortality in addition to other environmental stressors such as pollution, warming, and hypoxia, which affect larval herring growth, development, and survival. Therefore, potential effects of ocean acidification must be added to the growing list of anthropogenic disturbances leading to increased mortality in the early life phases, and they should be incorporated in future stock assessment models.

\section{ACKNOWLEDGMENTS}

Funding support was provided through the European Community's Seventh Framework Programme (FP7/20072013) "European Project on Ocean Acidification" (EPOCA, grant agreement N211384) and the European Marie Curie Initial Training Network "Calcification of Marine Organisms" (CalMarO). It was also supported by the project "Biological Impacts of Ocean ACIDification" (BIOACID), funded by the German Ministry for Education and Research (BMBF). Further funding was provided by the German Academic Exchange Service (DAAD). The experiments were conducted at the Norwegian National Mesocosm Centre, Espegrend, in cooperation with the Department of Biology, University of Bergen. The authors thank Vibeke Lokøy, Frank Midtøy, Oddbjørn Seljeset, and Mei-Yu Chang for their help with the experiment and Richard Bellerby for his help with water chemistry. Many thanks go to Paul Somerfield for his support in statistics. A. Y. Frommel, A. Folkvord, A. J. Geffen, C. Clemmesen, R. Maneja, and U. Piatkowski designed the experiment. A. Y. Frommel, A. Folkvord, A. J. Geffen, C. Clemmesen, and R. Maneja performed the experiment. D. Lowe, C. K. Pascoe, and A. Y. Frommel performed the histological analysis. A. Y. Frommel, D. Lowe, and C. Clemmesen analyzed data. A. Y. Frommel and C. Clemmesen wrote the main paper.

\section{Literature Cited}

Allen, J. M., J. H. S. Blaxter, and E. J. Denton. 1976. The functional anatomy and development of the swimbladderinner ear-lateral line system in herring and sprat. Journal of the Marine Biological Association of the UK 56:471-486.

Bailey, K. M., and E. D. Houde. 1989. Predation on eggs and larvae of marine fishes and the recruitment problem. Advances in Marine Biology. 25:1-83.
Bancroft, J. D., and A. Stevens. 1975. Histopathological stains and their diagnostic uses. Churchill Livingstone, London, UK.

Baumann, H., S. C. Talmage, and C. J. Gobler. 2012. Reduced early life growth and survival in a fish in direct response to increased carbon dioxide. Nature Climate Change 2:38-41.

Bekkevold, D., C. Andre, T. G. Dahlgren, L. A. W. Clausen, E. Torstensen, H. Mosegaard, G. R. Carvalho, T. B. Christensen, E. Norlinder, and D. E. Ruzzante. 2005. Environmental correlates of population differentiation in Atlantic herring. Evolution 59:2656-2668.

Belchier, M., et al. 2004. Recruitment studies: manual on precision and accuracy of tools. ICES Techniques in Marine Environmental Sciences, No. 33. International Council for the Exploration of the Sea, Copenhagen, Denmark.

Bellerby, R. G. J., A. Olsen, T. Furevik, and L. A. Anderson. 2005. Response of the surface ocean $\mathrm{CO}_{2}$ system in the Nordic Seas and North Atlantic to climate change. Pages 189-197 in H. Drange, T. Dokken, T. Furevik, R. Gerdes, and W. Berger, editors. The Nordic Seas: An Integrated Perspective. Geophysical Monograph Series 158, American Geophysical Union, Washington, D.C., USA.

Bennett, H. S., A. D. Wyrick, S. W. Lee, and J. H. McNeil, Jr. 1976. Science and art in preparing tissues embedded in plastic for light microscopy, with special reference to glycol methacrylate, glass knives and simple stains. Stain Technology 51(2):71-97.

Biastoch, A., et al. 2011. Rising Arctic Ocean temperatures cause gas hydrate destabilization and ocean acidification. Geophysical Research Letters 38(8). http://dx.doi.org/10. 1029/2011GL047222

Bignami, S., I. C. Enochs, D. P. Manzello, S. Sponaugle, and R. K. Cowen. 2013a. Ocean acidification alters the otoliths of a pantropical fish species with implications for sensory function. Proceedings of the National Academy of Sciences USA 110:7366-7370.

Bignami, S., S. Sponaugle, and R. K. Cowen. 2013b. Response to ocean acidification in larvae of a large tropical marine fish, Rachycentron canadum. Global Change Biology 19:996-1006.

Blaxter, J. H. S., J. A. B. Gray, and A. C. G. Best. 1983. Structure and development of the free neuromasts and lateral line system of the herring. Journal of the Marine Biological Association of the UK 63:247-260.

Bodenstein, S. 2012. Effects of ocean acidification and temperature on chloride cells in Atlantic herring (Clupea harengus) embryos and larvae. Diploma thesis. ChristianAlbrechts-University of Kiel, Kiel, Germany.

Buckley, L. J., E. M. Caldarone, and C. Clemmesen. 2008. Multi-species larval fish growth model based on temperature and fluorometrically derived RNA/DNA ratios: results from a meta-analysis. Marine Ecology Progress Series 371:221232.

Checkley, D. M., A. G. Dickson, M. Takahashi, J. A. Radich, N. Eisenkolb, and R. Asch. 2009. Elevated $\mathrm{CO}_{2}$ enhances otolith growth in young fish. Science 324:1683.

Clemmesen, C. 1993. Improvements in the fluorometric determination of the RNA and DNA content of individual marine fish larvae. Marine Ecology Progress Series 100:177183.

Cripps, I. L., P. L. Munday, and M. I. McCormick. 2011. Ocean acidification affects prey detection by a predatory reef fish. PLoS ONE 6:e22738.

Cushing, D. H., J. H. S. Blaxter, and A. J. Southward. 1990. Plankton production and year-class strength in fish populations: an update of the match/mismatch hypothesis. Advances in Marine Biology 26:249-293.

Denman, K., J. R. Christian, N. Steiner, H. O. Pörtner, and Y. Nojiri. 2011. Potential impacts of future ocean acidification on marine ecosystems and fisheries: current knowledge and recommendations for future research. ICES Journal of Marine Science 68:1019-1029. 
de Silva, C. 1974. Development of the respiratory system in herring and plaice larvae. Springer Verlag, Berlin, Germany.

Devine, B., P. Munday, and G. Jones. 2011. Homing ability of adult cardinalfish is affected by elevated carbon dioxide. Oecologia 168:269-276.

Dixson, D. L., P. L. Munday, and G. P. Jones. 2010. Ocean acidification disrupts the innate ability of fish to detect predator olfactory cues. Ecology Letters 13:68-75.

Donelson, J. M., P. L. Munday, M. I. McCormick, and C. R. Pitcher. 2011. Rapid transgenerational acclimation of a tropical reef fish to climate change. Nature Climate Change 2:30-32.

Doyle, M. J. 1977. Morphological staging system for larval development of herring, Clupea harengus L. Journal of the Marine Biological Association of the UK 57:859-867.

Drinkwater, K. F. 2005. The response of Atlantic cod (Gadus morhua) to future climate change. ICES Journal of Marine Science 62:1327-1337.

Fabry, V. J., J. B. McClintock, J. T. Mathis, and J. M. Grebmeier. 2009. Ocean acidification at high latitudes: the bellweather. Oceanography 22:160-171.

Fassbender, A. J., C. L. Sabine, R. A. Feely, C. Langdon, and C. W. Mordy. 2011. Inorganic carbon dynamics during northern California coastal upwelling. Continental Shelf Research 31:1180-1192.

Feely, R. A., S. R. Alin, J. Newton, C. L. Sabine, M. Warner, A. Devol, C. Krembs, and C. Maloy. 2010. The combined effects of ocean acidification, mixing, and respiration on $\mathrm{pH}$ and carbonate saturation in an urbanized estuary. Estuarine, Coastal and Shelf Science 88:442-449.

Feely, R. A., C. L. Sabine, J. M. Hernandez-Ayon, D. Ianson, and B. Hales. 2008. Evidence for upwelling of corrosive "acidified" water onto the continental shelf. Science 320:1490-1492.

Ferrari, M. C. O., D. L. Dixson, P. L. Munday, M. I. McCormick, M. G. Meekan, A. Sih, and D. P. Chivers. 2011. Intrageneric variation in antipredator responses of coral reef fishes affected by ocean acidification: implications for climate change projections on marine communities. Global Change Biology 17:2980-2986.

Ferrari, M. C. O., M. I. McCormick, P. L. Munday, M. G. Meekan, D. L. Dixson, O. Lönnstedt, and D. P. Chivers. 2012. Effects of ocean acidification on visual risk assessment in coral reef fishes. Functional Ecology 26:553-558.

Folkvord, A., G. Blom, A. Johannessen, and E. Moksness. 2000. Growth dependent age estimation in herring (Clupea harengus L.) larvae. Fisheries Research 46:91-103.

Franke, A., and C. Clemmesen. 2011. Effect of ocean acidification on early life stages of Atlantic herring (Clupea harengus L.). Biogeosciences Discussions 8:7097-7126.

Frommel, A. Y., R. Maneja, D. Lowe, A. M. Malzahn, A. J. Geffen, A. Folkvord, U. Piatkowski, T. B. H. Reusch, and C. Clemmesen. 2012. Severe tissue damage in Atlantic cod larvae under increasing ocean acidification. Nature Climate Change 2:42-46.

Frommel, A. Y., A. Schubert, U. Piatkowski, and C. Clemmesen. 2013. Egg and larval stages of Baltic cod, Gadus morhua, are robust to high levels of ocean acidification. Marine Biology 160:1825-1834.

Geffen, A. J. 2009. Advances in herring biology: from simple to complex, coping with plasticity and adaptability. ICES Journal of Marine Science 66:1688-1695.

Hedges, L. V., and I. Olkin. 1985. Statistical methods for metaanalysis. Academic Press, Orlando, Florida, USA.

Hill, A. J., C. V. Howard, and A. R. Cossins. 2002. Efficient embedding technique for preparing small specimens for stereological volume estimation: zebrafish larvae. Journal of Microscopy 206:179-181.

Hiroi, J., T. Kaneko, and M. Tanaka. 1999. In vivo sequential changes in chloride cell morphology in the yolk-sac membrane of Mozambique tilapia (Oreochromis mossambi- cus) embryos and larvae during seawater adaptation. Journal of Experimental Biology 202:3485-3495.

Hofmann, G. E., et al. 2011. High-frequency dynamics of ocean pH: a multi-ecosystem comparison. PLoS ONE 6:e28983.

Hurst, T. P., E. R. Fernandez, J. T. Mathis, J. A. Miller, C. M. Stinson, and E. F. Ahgeak. 2012. Resiliency of juvenile walleye pollock to projected levels of ocean acidification. Aquatic Biology 17:247-259.

Huwer, B., C. Clemmesen, P. Grønkjær, and F. W. Köster. 2011. Vertical distribution and growth performance of Baltic cod larvae-Field evidence for starvation-induced recruitment regulation during the larval stage? Progress in Oceanography 91:382-396.

Hwang, P.-P., and T.-H. Lee. 2007. New insights into fish ion regulation and mitochondrion-rich cells. Comparative Biochemistry and Physiology Part A: Molecular and Integrative Physiology 148:479-497.

Iles, T. D., and M. Sinclair. 1982. Atlantic herring: stock discreteness and abundance. Science 215:627-633.

IPCC. 2007. Climate change 2007-the physical science basis: working group I contribution to the fourth assessment report of the intergovernmental panel on climate change. S. Solomon, D. Qin, M. Manning, Z. Chen, M. Marquis, K. B. Averyt, M. Tignor, and H. L. Miller, editors. Cambridge University Press, Cambridge, UK.

Jutfelt, F., K. Bresolin de Souza, A. Vuylsteke, and J. Sturve. 2013. Behavioural disturbances in a temperate fish exposed to sustained high- $\mathrm{CO}_{2}$ levels. PLoS ONE 8:e65825.

Kikkawa, T., J. U. N. Kita, and A. Ishimatsu. 2002. Effects of $\mathrm{CO}_{2}$ on early development and growth of red sea bream (Pagrus major). Fisheries Science Research 68:637-638.

Köhler, A. 1991. Lysosomal perturbatons in fish liver as indicators of toxic environmental pollution. Comparative Biochemistry and Physiology Part C: Comparative Pharmacology 100:123-127.

Kroeker, K. J., R. L. Kordas, R. N. Crim, and G. G. Singh. 2010. Meta-analysis reveals negative yet variable effects of ocean acidification on marine organisms. Ecology Letters 13:1419-1434.

Lamichhaney, S., et al. 2012. Population-scale sequencing reveals genetic differentiation due to local adaptation in Atlantic herring. Proceedings of the National Academy of Sciences USA 109:19345-19350.

Lawrence, A. J. 2003. The role of modelling in fish and fishery ecotoxicology. Pages 319-333 in A. Lawrence and K. Hemmingway, editors. Effects of pollution on fish: molecular effects and population responses. Blackwell Science, Oxford, UK

Le Pecq, J. B., and C. Paoletti. 1966. A new fluorometric method for RNA and DNA determination. Analytical Biochemistry 17:100-107.

Le Quéré, C., et al. 2009. Trends in the sources and sinks of carbon dioxide. Nature Geoscience 2:831-836.

Limborg, M. T., S. J. Helyar, M. de Bruyn, M. I. Taylor, E. E. Nielsen, R. Ogden, G. R. Carvalho, FPT Consortium, and D. Bekkevold. 2012. Environmental selection on transcriptome-derived SNPs in a high gene flow marine fish, the Atlantic herring (Clupea harengus). Molecular Ecology 21:3686-3703.

Lowe, D. M., M. N. Moore, and B. M. Evans. 1992. Contaminant impact on interactions of molecular probes with lysosomes in living hepatocytes from dab Limanda limanda. Marine Ecology Progress Series 91:135-140.

Maneja, R. H., A. Y. Frommel, H. I. Browman, C. Clemmesen, A. J. Geffen, A. Folkvord, U. Piatkowski, C. M. F. Durif, R. Bjelland, and A. B. Skiftesvik. 2013a. The swimming kinematics of larval Atlantic cod, Gadus morhua L., are resilient to elevated seawater $p \mathrm{CO}_{2}$. Marine Biology 160:1963-1972.

Maneja, R. H., A. Y. Frommel, A. J. Geffen, A. Folkvord, U. Piatkowski, M. Y. Chang, and C. Clemmesen. 2013b. Effects 
of ocean acidification on the calcification of otoliths of larval Atlantic cod Gadus morhua. Marine Ecology Progress Series 477:251-258.

Meekan, M. G., L. Vigliola, A. Hansen, P. J. Doherty, A. Halford, and J. H. Carleton. 2006. Bigger is better: sizeselective mortality throughout the life history of a fastgrowing clupeid, Spratelloides gracilis. Marine Ecology Progress Series 317:237-244.

Melzner, F., J. Thomsen, W. Koeve, A. Oschlies, M. A. Gutowska, H. W. Bange, H. P. Hansen, and A. Körtzinger. 2012. Future ocean acidification will be amplified by hypoxia in coastal habitats. Marine Biology. http://dx.doi.org/10. 1007/s00227-012-1954-1

Merilä, J. 2012. Evolution in response to climate change: in pursuit of the missing evidence. Bioessays 34:811-818.

Miller, G. M., S. A. Watson, J. M. Donelson, M. I. McCormick, and P. L. Munday. 2012. Parental environment mediates impacts of increased carbon dioxide on a coral reef fish. Nature Climate Change 2:858-861.

Munday, P., M. Gagliano, J. M. Donelson, D. L. Dixson, and S. R. Thorrold. 2011a. Ocean acidification does not affect the early life history development of a tropical marine fish. Marine Ecology Progress Series 423:211-221.

Munday, P. L., N. E. Crawley, and G. E. Nilsson. $2009 a$. Interacting effects of elevated temperature and ocean acidification on the aerobic performance of coral reef fishes. Marine Ecology Progress Series 388:235-242.

Munday, P. L., D. L. Dixson, J. M. Donelson, G. P. Jones, M. S. Pratchett, G. V. Devitsina, and K. B. Doving. $2009 b$. Ocean acidification impairs olfactory discrimination and homing ability of a marine fish. Proceedings of the National Academy of Sciences USA 106:1848-1852.

Munday, P. L., D. L. Dixson, M. I. McCormick, M. Meekan, M. C. O. Ferrari, and D. P. Chivers. 2010. Replenishment of fish populations is threatened by ocean acidification. Proceedings of the National Academy of Sciences USA 107:12930-12934.

Munday, P. L., J. M. Donelson, D. L. Dixson, and G. G. K. Endo. 2009c. Effects of ocean acidification on the early life history of a tropical marine fish. Proceedings of the Royal Society B 276:3275-3283.

Munday, P. L., V. Hernaman, D. L. Dixson, and S. R. Thorrold. 2011b. Effect of ocean acidification on otolith development in larvae of a tropical marine fish. Biogeosciences 8:1631-1641.

Nakagawa, S., and T. M. Foster. 2004. The case against retrospective statistical power analyses with an introduction to power analysis. Acta Ethologica 7:103-108.

Nash, R. D., and M. Dickey-Collas. 2005. The influence of life history dynamics and environment on the determination of year class strength in North Sea herring (Clupea harengus L.). Fisheries Oceanography 14(4):279-291.

Nilsson, G. E., D. L. Dixson, P. Domenici, M. I. McCormick, C. Sorensen, S.-A. Watson, and P. L. Munday. 2012. Nearfuture carbon dioxide levels alter fish behaviour by interfering with neurotransmitter function. Nature Climate Change 2:201-204.
Parker, L. M., P. M. Ross, and W. A. O'Connor. 2011. Populations of the Sydney rock oyster, Saccostrea glomerata, vary in response to ocean acidification. Marine Biology 158:689-697.

Parker, L. M., P. M. Ross, W. A. O'Connor, L. Borysko, D. A. Raftos, and H.-O. Pörtner. 2012. Adult exposure influences offspring response to ocean acidification in oysters. Global Change Biology 18:82-92.

Pierrot, D., E. Lewis, and D. W. R. Wallace. 2006. CO2SYS for Excel. Program developed for $\mathrm{CO} 2$ systems calculations, ORNL/CDIAC-105. Carbon Dioxide Information Centre, Oak Ridge National Laboratory, U.S. Department of Energy, Oak Ridge, Tennessee, USA.

Pörtner, H. O., M. Langenbuch, and A. Reipschlaeger. 2004. Biological impact of elevated ocean $\mathrm{CO}_{2}$ concentration: lessons from animal physiology and Earth history. Journal of Oceanography 60:705-718.

Rossoll, D., R. Bermudez, H. Hauss, K. G. Schulz, U. Riebesell, U. Sommer, and M. Winder. 2012. Ocean acidification-induced food quality deterioration constrains trophic transfer. PLoS ONE 7:e34737.

Sabine, C. L., et al. 2004. The oceanic sink for anthropogenic $\mathrm{CO}_{2}$. Science 305:367-371.

Sayer, M. D. J., J. P. Reader, and T. R. K. Dalziel. 1993. Freshwater acidification: effects on the early-life stages of fish. Reviews in Fish Biology and Fisheries 3:95-132.

Seljeset, O., K. Vollset, A. Folkvord, and A. J. Geffen. 2010. The role of prey concentration and size range in the growth and survival of larval cod. Marine Biology Research 6:251262.

Sinclair, M., and M. J. Tremblay. 1984. Timing of spawning of Atlantic herring (Clupea harengus harengus). Canadian Journal of Fisheries and Aquatic Sciences 41:1055-1065.

Steinacher, M., F. Joos, T. L. Frolicher, G. K. Plattner, and S. C. Doney. 2009. Imminent ocean acidification in the Arctic projected with the NCAR global coupled carbon cycleclimate model. Biogeosciences 6:515-533.

Stumpp, M., J. Wren, F. Melzner, M. Thorndyke, and S. T. Dupont. 2011. $\mathrm{CO}_{2}$ induced seawater acidification impacts sea urchin larval development I: Elevated metabolic rates decrease scope for growth and induce developmental delay. Comparative Biochemistry and Physiology Part A: Molecular and Integrative Physiology 160:331-340.

Thünen Institute of Baltic Sea Fisheries. 2013. Hering. http:/ fischbestaende.portal-fischerei.de/Fischarten/?c=stockgroup\& $a=$ detail\&sgroup_id $=4$

Vollset, K. W., O. Seljeset, O. Fiksen, and A. Folkvord. 2009. A common garden experiment with larval Northeast Arctic and Norwegian coastal cod cohorts in replicated mesocosms. Deep-Sea Research Part II: Topical Studies in Oceanography 56:1984-1991.

Von Dewitz, B. 2012. A historical reconstruction of the Baltic Sea $\mathrm{pH}$ environment experienced by marine organisms. Diploma thesis. Christian-Albrechts-University of Kiel, Kiel, Germany.

Wales, W., and P. Tytler. 1996. Changes in chloride cell distribution during early larval stages of Clupea harengus. Journal of Fish Biology 49:801-814. 